\title{
Punishment, rewards and the importance of desert
}

\author{
GUSTAVO A. BEADE *
}

\section{Introduction}

We tend to think that if we are rewarded or punished, it is due to the fact that we deserve it - that we did something that merits such praise or blame. However, it is difficult to reach a consensus as to the criteria that could possibly determine the basis for desert i.e. determining which conducts deserve rewards and which deserve blame. Among other reasons, this is why desert is uncharted philosophical territory. ${ }^{1}$ Here, I am interested in its relationship with criminal responsibility and criminal punishment.

* Gustavo A. Beade, Professor of Criminal Law and Legal Theory, School of Law, Universidad Austral de Chile; email: gustavo.beade@uach.cl.

I have developed some of these ideas in different and brief discussions with Antony Duff, Sandra Marshall, Serena Olsaretti and Jaime Malamud Goti. Many thanks to Michelle Dempsey and Carola Lehmaher for improving the style and clarity of my ideas. I am very grateful to Santiago Mollis, Fernando Bracaccini, Matias Parmigiani, José Peralta, Maximiliano Vargas, Bruno Rusca, Romina Rekers, Carlos Villanueva, Daniela Pererya, Belén Gulli and other members of WS in Córdoba (Argentina) for their helpful comments on early drafts of this paper. I am very thankful to Antony Duff and Jørn Jacobsen for detailed written comments. Many thanks to an anonymous peer reviewer for valuable comments. I rewrote parts of this paper as a guest researcher at the University of Graz (Department of Moral and Political Philosophy) and at theYale Law School as a Fellow in the Yale's law Center for Law and Philosophy. I would like to thank these institutions for their hospitality and in particular to Lukas Meyer and Gideon Yaffe.

1 Sher, Desert (Princeton University Press 1989) p. 3. However, there is an increase in the production of works on this topic. See among others, Scanlon, Why Does Inequality Matter? (Oxford University Press 2018) Ch. 8; Kagan, The Geometry of Desert (Oxford University Press 2012) and Olsaretti (ed.), Desert and Justice (Oxford University Press 2003).

This is an Open-access article distributed under the terms of the Creative Commons Attribution 3.0 Unported License (http://creativecommons.org/licenses/ by/3.0/, permitting all use, distribution, and reproduction in any medium, provided the original work is properly cited. 
My aim in this work is not to reject desert or deny its importance in criminal punishment. ${ }^{2}$ Instead, I will rework the concept of desert defended mainly by retributivism. I will approach this issue by considering the problem of desert in relation to rewards and punishment. Furthermore, I distinguished between two particular ways in which desert plays different and important roles: formal desert and material desert.

The paper goes as follows: I start with an outline of the concept of desert in criminal law theory (2), then I briefly explain what the concept of desert is (3) and discuss later (in 4) some conceptual issues associated with the notion of desert and developed the idea of formal desert and material desert. Then, I refer to its implication in rewards and punishment as well (in 4 and 5). I conclude with some final reflections (6).

\section{Desert in criminal law theory}

Legal philosophers tend to adopt different positions regarding the meaning of desert. Generally in criminal law theory, except some critical positions against the concept of desert, ${ }^{3}$ retributivists think that moral wrongdoing is an appropriate desert basis and suffering is the outcome that wrongdoers deserve. ${ }^{4}$ Moreover, desert is the basis for both blame and punishment. For instance, according to Larry Alexander and Kimberly Ferzan desert is necessary and sufficient for punishment. ${ }^{5}$ Furthermore, retributive desert basis is a culpable action. ${ }^{6}$ Leo Zaibert argues that according to retributivism, punishment is justified by desert, and desert does not require looking at the consequences of punishment at all. ${ }^{7}$ Since retributivism dominates the desert discussion I will concentrate here at the retributivist theories. However, despite the fact that retributivism have long sustained the idea that whoever commits a crime should receive a deserved punishment, what retributivism is needs to be clarified. ${ }^{8}$ According to Douglas Husak retributivism is not really the name of a particular theory of punishment. Instead, it is the name of a tradition or group of theories that share

2 This view in Tadros, The Ends of Harm: The Moral Foundations of Criminal Law (Oxford Univesity Press 2011) p. 42.

3 See Tadros 2011 p. $60 \mathrm{ff}$.

$4 \quad$ See for instance, Moore, Placing Blame: A Theory of Criminal Law (Oxford Univesity Press 1997); Alexander and Ferzan, Crime and Culpability, A Theory of Criminal Law (Cambridge University Press 2009); Alexander and Ferzan, Reflections on Crime and Culpability (Cambridge University Press 2018).

$5 \quad$ Alexander and Ferzan 2009 p. 7.

$6 \quad$ Alexander and Ferzan 2018 p. 181.

$7 \quad$ Zaibert, Punishment and Retribution (Routledge 2006) p. 97.

8 See the complexity of the recent debate in White (ed.), Retributivism: Essays on Theory and Policy (Oxford University Press 2011) and Tonry (ed.), Retributivism Has a Past: Has It a Future? (Oxford University Press 2011). 
some loose similarities. ${ }^{9}$ In this paper, I would like to address the more traditional positions, which originated most generally in Kant. ${ }^{10}$ This form of retributivism, which I refer to as pure retributivism, is connected to the ideal of giving each person what she deserves, this being either a reward or punishment. ${ }^{11}$

Pure retributivism argues that whatever happens in the future is irrelevant for the justification of punishment. ${ }^{12}$ It is a sufficient reason to punish that the person deserves it, even if such punishment does not change future behavior at all. ${ }^{13}$ Based on this characterisation, pure retributivism seek, not primarily for the socially useful punishment, but for the just punishment: the punishment that the society has the right to inflict. ${ }^{14}$ These guidelines shed some light on the idea of imposing punishment based on the pure retributivist ideal. ${ }^{15}$

\section{The basis of desert}

The concept of desert is a complex and difficult issue to explain in the abstract, without any reference to a specific context. However, I did not say much about desert in general. Basically, desert claims for recognition of something a person has done. There are many notions related to the concept of desert that led to endless discussions regarding the criteria of its determination. In order to speak of desert, it is necessary for someone to act in a way that merits a reward, promotion, blame or punishment. Reasons are also required to justify that someone is deserving of something. These actions and reasons are known as the basis of desert. ${ }^{16}$ This is why it would be impossi-

$9 \quad$ See Husak, Retributivism in Extremis, 32 Law and Philosophy (2013) p. 4.

10 See Murphy and Coleman, Philosophy of Law, An introduction to Jurisprudence - revised edition (Westview Press 1990) pp.120 ff.; see also Tadros, The Ends of Harm (Oxford Legal Philosophy 2011) p. $21 \mathrm{ff}$.

$11 \quad$ Moore 1997 pp. $197 \mathrm{ff}$. Other versions of (impure) retributivism (e.g. communicative theories of punishment) take desert into account. However, on my view desert plays a less important role in communicative theories than in pure retributivism.

12 Nevertheless, there are other many types of retributive theorists who afford a place for desert but include consequences in their rationale for punishment. See Husak 2013 p. 5.

$13 \quad$ Moore, Act and Crime (Clarendon Press 1993) p. 53.

14 Murphy, Retribution Reconsidered (Kluwer Academic Publishers 1992) p. 21.

15 Nevertheless, pure retributivists disagree about how we understand wrongdoing. According to a group of them, the outcomes of one's decision can contribute to the desert basis and hence they can make a difference to the degree of punishment deserved. While Michael Moore thinks that blameworthiness provides the desert basis and that outcomes matter to blameworthiness, Larry Alexander and Kimberly Ferzan think that culpability provides the desert basis, and the outcomes don't matter to culpability. In fact, Alexander and Ferzan argue that an agent who attempted a crime vis a vis an agent who committed the same crime deserve equal punishment. See Tadros 2011 p. 67.

16 Feinberg, Justice and Personal Desert in Doing and Deserving, Essays in the Theory of Responsibility (Princeton University Press 1970) p. 58. 
ble, for example, to claim that anyone deserves congratulations or respect without any reasons to support such a claim. These reasons refer to actions performed by an agent, namely, the subject of desert. It is therefore inappropriate, for example, to claim that a student deserves a higher grade by arguing that this would prevent him from parental scolding or physical abuse. The student must show, among other things, proper skills, good behavior in class, and also, good performance in his examinations.

Under some circumstances, the condition of desert is related to the completion of a specific activity. Let us take, for instance, the example of a law degree: the idea that someone would claim to deserve one after merely reading a substantial amount of the bibliography related to classes taught in Law School would seem comical. Deserving a degree implies complying with certain rules that are partly administrative (attending class and taking exams) and partly related to curricular contents (passing exams and submitting essays). Even though this example of this particular notion of desert might seem trivial or basic, it is true in the sense that we tend to believe that one can only deserve something after completing the basis of desert. In the example above, that would be to follow the appropriate steps and rules to completion. This view possibly constitutes a notion of basic desert. Nevertheless, whenever discussing desert we do so thinking about something beyond this perception.

In addition to these basic claims of desert, there are also cases of people deserving positive recognition - admiration, credit or reward - without ever receiving it. This situation is likely to continue unless they qualify for institutionally regulated forms of positive recognition but even then, there is no guarantee that might assure obtaining the desired prize. ${ }^{17}$ Let us think about the number of women that have lived, sacrificing themselves for their children and husbands, with the sole objective of keeping their home in order and yet, have never received the least recognition by others. There are other examples of unrecognised persons. For instance, the writer Jorge Luis Borges - who, in spite of deserving to win the Nobel Prize, never did so - or of the emergence of prominent texts and countless works of art that have only been publicly valued years after their creation. The history of art repeatedly laments the numerous artists that have died in absolute poverty, deprived of any public recognition by their contemporaries.

In the following section I will discuss some conceptual issues associated with the notion of desert and introduce two ways in which desert could be understood: formal and material. 


\section{Desert, rewards and results}

Under some circumstances, the notion of desert is connected to the results of our actions. Some philosophers consider actions to be successful when, for instance, they entail a prize or a positive recognition. ${ }^{18}$ It would then be possible to argue that whoever wins a sports competition deserves a prize for it. In sports competitions there is a very clear distinction between winners and losers. In certain sports, it would seem that the winner. i.e. the one that gets the prize, is always also the one who deserves the prize: 'he won because he deserved it'. This phrase may be tricky; it is incapable of offering reasonable justifications for desert. This is because they are solely based on the outcome of a given competition. It refers to what the agent was able or was not able to achieve. If this is correct, then we could say that, in sports, what matters most is winning, i.e. winning is the desert base. Thus, whoever won the competition deserved it and whoever did not, simply did not. The result of the competition is the justification of desert. This is what I refer to as formal desert.

Formal desert is related to the act of winning or losing subject to specific rules set by the particular sport or competition. This would mean, for example, that I would be prevented from disqualifying the result of that essay contest that happened to favor my rival over me. According to the regulations established by the contest, he won, and I did not. At some point, accepting the notion of formal desert implies accepting the occurrence of certain facts. These results may not be able to cover everything that occurred and also, there may be many aspects that are not reflected in a winner/loser chart board. Nevertheless, this notion provides us with some certainties about what happened in a competition, for example. However, it should be noted that, under some circumstances, this notion prevents us from having a more clear and deeper understanding of the events that took place. For instance, particular causes that originate a singular outcome cannot be understood by looking at a board. How did she win? What happened with her rival?

Alternatively, there is an essential way in which we refer to desert that addresses circumstances beyond the established rules. I refer to this notion as material desert. Material desert recognises, for example, the person performing a certain activity with both elegance and style. Think of cases in which someone displays beautiful sportsmanship: a performance that is attractive for the viewer either in itself or by a declaration of distinction of a 'moral winner' of a competition. These athletes are agents that should have won but for some reason have failed to do so. They gain admiration and respect, sometimes even more admiration and respect than the actual winner of the competition. It is notable that in sports there is special recognition for those who 
were successful (formal desert), as well as for those who showed incredible skill and talent beyond their partial success (material desert).

In this way, positive recognition in sports operates under a criterion of desert that runs parallel and unaffected by the mere statistical measurement of formal success (subject to the rules of the specific sport-formal desert). The criterion of formal desert requires determining a winner and its basis is one of a normative nature: the kind that generally rules a competition. In cases such as these, not everyone can be a winner. There will be winners and losers, but we cannot reduce all merit to a single result of a competition. Material desert does not take into consideration the traditional criterion, which focuses on there being one winner, and that this occurred because the person deserved it. Otherwise, we would be forced to say that Peter had greater merit over Joe because he, and not his competitor, won the annual marathon. It should be this way, regardless of whether Joe led the competition during almost the entire race and 'unluckily' tripped over a rock ten meters before the finish line. Using this same example, I wonder: Should we not reward Peter because we believe that he did not deserve to win? Should we give Joe the prize instead who, after falling down, came in number 150 in the race? I also wonder what would happen if we were to find out that Peter, the winner, is not a good sportsman: that he stays up all night, smokes an uncountable number of cigarettes per hour and drinks whiskey for breakfast; that he does not train much, but that his incredible physical capacity allows him to be the runner-up during the entire race and to finally win; while Joe, on the other hand, wakes up every day at 7 a.m. and trains until sunset. However, we should say that Peter deserves the prize for winning the marathon (formal desert) and Joe deserves our admiration and sympathy (material desert).

When we adopt the formal desert perspective we forget to take into account luck as a factor in any given result. The fact that an outcome takes place is not the only factor to consider; it certainly does not offer all we need to know in order to justify our judgments. Successful results also imply displaying a winner's skills. The outcome will allow us to establish an order to enable the classification of the winner and the loser, who wins first place and who wins second place, etc. Nonetheless, formal desert does not always allow us to know if the winner is the one who 'materially' deserved it most. We can suppose that there is more than one overall measure of desert. Sometimes we can say that A formally deserves the prize and B materially deserves it.

In a competition, for instance, we begin by considering other circumstances, regardless of the competition's outcome. When we realise that the result of a game was unjust, when the winner concretes a lucky shot or when the referee fails to be fair. At this point complex issues related to material desert come into play. This understanding of desert might not provide us with a higher degree of certainty to determine one overall 
measure of desert but, at least, it avoids in a more interesting way the traps that come with disregarding luck. These traps we fall into can sometimes lead us to wrongly conclude that whoever wins the prize is the best player. This thinking may lead to serious misunderstandings. The person who wins a competition only won a single competition. We cannot reduce the issue so drastically, but we do actually have to take a few additional points into consideration, just as it would be possible by taking into account a material criterion of deserving. Furthermore, sometimes we are able to identify a particular reference point that links formal desert with material desert: a typical form of material desert. For example, winning the World Cup in football entails a typical form of material desert, i.e. being the best football team in the competition. This typical form of material desert entailed by the formal desert allow us to nuance our desert considerations in a more detailed way. Sometimes, the best football team won the World Cup but the finalist in the same competition played the best football during the tournament and had the best player elected. In this particular case, we are able to recognise the team winner of the world cup (formal desert) and the team who played the best football in the world cup (typical form of material desert). In addition, we can also have the chance to recognise the team who respected more the rules with a 'Fair Play' prize (material desert).$^{19}$ In brief, my aim is to spell out the idea that we need to recognise that we do use desert in many different ways when think about rewards but also when we think about punishment.

Next, I would like to think of the issue of desert, not only in terms of rewards, but also in terms of blame and punishment.

\section{Pure retributivism, desert and luck}

The scope of what is included in criminal outcomes by pure retributivism is quite problematic. According to Michael Moore, an agent who commits a crime should be punished far more than the one who unsuccessfully attempted it. Moore's distinction reflects the concept that each should get what they deserve in proportion to their conduct. This type of pure retributivism considers desert to be formal. It is formal be-

19 Many thanks to Jørn Jacobsen for providing me this example and suggesting me to improve this part of the text. 
cause a criminal outcome is enough to justify the imposition of graver punishment. ${ }^{20}$ Nevertheless, a criminal outcome could be considered a reference for two different (but related) things. On the one hand, the harm that the crime committed caused; on the other hand, the fact that a norm is breached. Regardless of these alternatives the conclusion is the following: if an agent commits a crime the agent deserves more punishment than if he only attempts to commit it. Thus, punishment would be greater because of the magnitude of desert. Causing a criminal outcome is reason enough to justify punishment. ${ }^{21}$

However, relying on criminal outcomes it should be problematic to pure retributivism. As I said before, there is not a necessary relationship between an outcome and an agent's desert. It is about formally deserving punishment for committing a crime. Here is where the formulation gets circular: he deserves to be punished because he committed murder; he committed murder and for that reason he deserves to be punished. Pure retributivism tends to ignores not only material desert, but also different criteria of desert. However, it seems to me that there is much more to say in, for example, a murder case. In fact, murder is a crime and the offender deserves punishment because of his action (formal desert); murder is also typically a serious crime (typical material desert); but sometimes there are different kind of mitigation circumstances even for murder - at times related to luck factors - that probably change what murder deserves (material desert). In the same way a person winning a race does not always deserve it more than the others that have not won, who causes a criminal outcome does not necessarily deserve a graver punishment than a person who failed to cause it. I try to put this clearly: if two agents, each of whom try to produce a criminal outcome, does the mere fact that one succeeds and the other does not make a difference to what each deserves by way of punishment? This seems uncertain to me and not enough to defend this position. Why does a speedy ambulance driver who prevents a person from dying modify the agent's desert? Or think about a car accident in which driver A driving carefully kills pedestrian $B$ while driver $C$ driving recklessly kills pe-

20 Someone could argue that the Alexander/Ferzan's approach (presented in section 2) will be a valid alternative to tackle this problem. However, it is unpersuasive to argue that equal intent for an action, regardless of whether the action has been completed or not, should deserve equal punishment. This is due to the fact that this notion of equality is inadequate for the allocation of blame and rewards. Therefore: what happens if we try to apply the Alexander/Ferzan's approach to rewards? On the one hand, if our communities should reward and recognize good intents, everyone should receive equal rewards. And so, this view would reward equally, for example, a person engaged in manipulating chemical substances in her private lab as a hobby, looking for the cure of some fatal disease, and Albert Einstein. According to Jaime Malamud Goti, should this be the case, there would be no space available in parks and public squares to build monuments for generals, captains and soldiers. See Malamud Goti, Suerte, moralidad y responsabilidad penal (Hammurabi 2008) p. 64.

21 See Moore, Causation and Responsibility: An Essay in Law, Morals and Metaphysics (Oxford University Press 2009), pp. 20-33. 
destrian D. Both caused the same criminal outcome; however, do they both deserve the same punishment? Clearly, most would believe they deserve different amounts of blame and punishment. Hence, why should we argue that criminal outcomes implies deserved punishment? What happened with luck factors that influenced criminal outcomes?

Pure retributivism does not offer good reasons to explain why the completion of the target crime makes its criminal agent deserving of graver punishment than in the case of agents with graver intent (or with the same intent) acting without harming others. Having caused a result does not imply having made the best efforts to achieve it. There are innumerable factors linked to luck - in particular those circumstances which are beyond our control - that influence the realisation of a certain result. This should modify the formal desert basis. However, pure retributivist pretend to avoid the influence of luck. ${ }^{22}$ The luck factor of a result lies in how our projects become a reality, that is, how our actions show their impact on the world after we intentionally perform them with our bodies. ${ }^{23}$ Admitting to the relevance of luck implies acknowledging that we need a nuanced conception of desert. Despite Borges deserving to win the Nobel Prize, the lack of such positive recognition does not modify our moral judgment regarding his talent for writing. In other words, Borges would not have been a better writer had he been awarded the Nobel Prize in Literature. This seems to imply that what matters is precisely that he deserved it, whether or not he actually received it. However, our notion of Borges as a writer remains unchanged in spite of not having received said award; he would also not have been considered a 'bad' writer had he received it. ${ }^{24}$

Just as in the case of rewards, desert in punishment is generally governed by mere formal criteria. As I argue before, this criterion holds an explicative sense in the world we live in. However, to be governed by criteria of formal desert is problematic because it recognises the influence of luck in our moral judgments but argues that is not controversial. Just as there are nuances regarding the success or failure attributed to certain behavior and agents, there are also important nuances in the matters of blame and punishment. Not only do we punish those whose actions modify the world in which we live in; we also punish those who are caught attempting to commit these actions. That is to say, not only those who are successful in their criminal attempt are

22 See for instance Alexander and Ferzan 2008 pp. 188-190.

$23 \quad$ Malamud Goti 2004 p. 863.

24 The notion of desert aims to contradict the idea that many things happen by chance. Those who strongly support the concept of desert would argue that it is possible to recognise something we have done as a product of 'luck'. They would add that it is our efforts employed in our behavior that allow us to deserve the good results we seek. I believe that luck plays an important role in criminal responsibility, however I cannot develop this argument here. 
punished but also those who try and failed in such an attempt. If we ever believed that we should react identically in the face of both scenarios of rewards and punishment, our practices of blame and censure would show us this is not so. While rewards recognise winners who formally deserve a prize and losers who materially deserve a different award, punishment recognises differences that should include formal and material desert alike. For instance, differences regarding mental states while committing a crime, risk offenses, omissions that cause criminal outcomes, justifications and excuses, and so on. Hardly, many of these circumstances cannot be explained only relying on formal desert. I guess that there should be a room for material desert that pure retributivism needs to recognise.

\section{Conclusion}

I have argued that we need to rework the concept of desert in criminal responsibility. Pure retributivists think about deserving blame and punishment in a monotonous way, and therefore I critise that they are not considering desert in a more nuanced way. This is why I have sketched the problem of desert in the rewards domain and very briefly developed the idea material desert and formal desert. While these two concepts seem to fit into specific rewards scenarios my goal was to explain why pure retributivists should make efforts to recognise that desert play different roles in criminal responsibility and that formal and material desert could be useful to understand better our practices of blame and punishment. 